true, but not the former. Let us test the case by that of the North Suffolk Cliff, which from Kessingland to Yarmouth, a distance of fifteen miles, forms the natural section of a tract of country of similar structure which extends inland for nearly forty miles; and over which tract, whenever pits show the junction of the sand with the clay, they disclose exactly the same features attending it as the cliff does. Now this cliff, except where the valley denudation interrupts it, is formed by a continuous deposit of undisturbed horizontally bedded sand, containing marine mollusca and other marine organisms, overlain nearly throughout by the morainic clay, often twenty, and averaging fully twelve feet in thickness, the junction of the two being absolutely undisturbed except in one or two places where, for a space of a very few yards only, the clay slightly dents into and disturbs the top of the sand, showing as it appears to me places where floes grounded; and the only departure from this in the district inland is that bosses of the contorted Drift occasionally protrude there through the sands. Now I say that it is a physical impossibility that the whole of this thick sheet of morainic elay, fifteen miles wide by forty long, can have been dragged for forty miles over the sand without either crumpling or destroying it in the least, and without incorporating part of such sand and of the contorted Drift bosses into itself. This impossibility becomes more striking if we supplement the weight of this sheet of clay by the many-fold greater weight of the ice which Mr. Geikie contends overlaid and dragged it, "gradually diminishing" though that ice may have been from the prodigious thickness usually appealed to by Mr. Geikie.

I hope that in the above I have made the distinction between our views clear; and I venture to think that $\mathrm{Mr}$. Geikie, with his numerous interglacial periods, his exaggerated ice-sheets, and his assumption of the truth of Dr. Croll's theory, is hardly the person who should charge those who differ from him with "preconceived ideas" in glacial geology.

S. V. Wood, jun.

February 16, 1878.

\title{
ON THE TRILOBITES OF THE SHINETON SHALES.
}

SrR,-Among the fossils described in Mr. Callaway's interesting paper on the Upper Cambrian Rocks in South Shropshire (Quart. Journ. Geol. Soc., vol. xxxiii. p. 652 seqq.), there are some Trilobites of whose relations to forms previously known I might venture a few suggestions.

I do not think that Conocoryphe monile is very nearly related to such species as $C$. striata. By the strongly-lobed glabella and the dotted marginal furrow, it approaches to Angelin's Euloma, a genus characteristic of the Swedish Ceratopyge Limestone, which occupies about the same position as the English Upper Tremadoc. The fauna of the Ceratopyge Limestone is decidedly Lower Silurian, but also the Tremadoc group-at least the Upper-has to me always seemed to be, palæontologically, more related to the Silurian than to the Cambrian. The Lower Graptolite Schists immediately overlying the 
Ceratopyge Limestone are a distinct equivalent of the English Skiddaw.

Conophrys can hardly be separated from the Shumardia of Billings (Pal. Foss. Canada, vol. i. p. 92), which occupies a somewhat similar, perhaps a little higher horizon. To the same genus probably also belongs the Battus pusillus of Sars (Isis, 1835, p. 334, t. viii. fig. $2=$ Agnostus or Olenus pusillus, Kjerulf), which occurs near Christiania together with Ceratopyge forficula.

As to Lichapyge, it cannot have any affinity to Paradoxides, and hardly to Lichas. I little doubt that it is most nearly allied to Remopleurides, if not a true Remopleurides. In some species of Remopleurides, as $R$. dorsospinifer, Portl., it is very usual to find the pygidium united with the two hindmost thoracal segments. The fossil described as Lichapyge would have almost the same shape, if the terminal limb had two denticles on either side.

The subgenus Platypeltis seems to be more nearly related to Niobe than to the genuine Asaphi. Also Niobe is characterized by not having the hypostoma forked.

G. LinNaRsson.

Grol. Survey Office, Stockholm, March $4 t h, 1878$.

\section{GEOLOGICAL MAP OF SCOTLAND.}

Sin,--Since the publication of my review of Prof. Geikie's Geological Map of Scotland, it has come to my knowledge that the vast mass of new detail inserted thereupon in the areas south of the Grampians, instead of being due to a digest of Survey work, is in truth the result of the author's recent personal investigations. The map has been the constant occupation of his leisure hours for many years, his summer holidays being generally given up to journeys for its extension and improvement. Even the remarkably minute mapping of the Old Red and Volcanic series of Fife and Forfar, the trappean belt of the Solway, etc., noted by us for especial commendation, was completed by himself before the Survey moved into those districts. Though this deprives the map of anything like an official character, it adds much to its general reliability. It is indeed highly satisfactory to feel assured that all the new work is by the same hand, and that consequently the details throughout are as trustworthy as those within the areas already covered by the Survey. Looked upon as the simple product of individual original research, the map is a monument of rare geologic skill and energy. The author is to be congratulated on having, single-handed, accomplished his task with a perfection and completeness that-however widely views may differ as to the expediency of his new systematic arrangements - has charmed all those whose opinion is worthy of a moment's consideration.

ST. ANDREws, March $20 t h$.

Chas. Lapworth.

DR. CARL MAYER ON THE ITALIAN TERTIARIES.

Sir,-In the last number of the "Bolletino del R. Comitato Geologico d'Italia" there are again several important papers on the Italian Tertiaries, but that of Dr. Carl Mayer calls for special atten- 